\title{
Typology of Climate Change Adaptation Measures in Polish Cities up to 2030
}

\author{
Eliza Kalbarczyk ${ }^{1}$ and Robert Kalbarczyk ${ }^{2, *(D)}$ \\ 1 Faculty of Human Geography and Planning, Adam Mickiewicz University in Poznań, \\ 61-680 Poznań, Poland; ekalb@amu.edu.pl \\ 2 Institute of Landscape Architecture, Faculty of Environmental Engineering and Geodesy, \\ Wrocław University of Environmental and Life Sciences, 50-357 Wrocław, Poland \\ * Correspondence: robert.kalbarczyk@upwr.edu.pl
}

Received: 19 August 2020; Accepted: 22 September 2020; Published: 24 September 2020

\begin{abstract}
Poland, like other countries in the world, increasingly experiences the ongoing climate change. However, the level of preparation of the country and its society for climate change in the second decade of the 21st century can be evaluated as low. The Municipal Adaptation Plans (MAPs) created in 2017-2019 became a subject of research studies whose main goal was to determine the typology of adaptation actions to be undertaken as part of MAPs in the 14 selected Polish cities in various geographical regions. Moreover, the type and scope of intended actions were analysed according to the planned amount of expenditure and from the perspective of sectors. The tasks accepted for implementation up to 2030 mainly relate to modernisation and development of transport systems and to actions connected with physical infrastructure. A large number of tasks and even a bigger scale of financial sources planned in the analysed MAPs for mitigation actions show that Polish cities are at an initial stage of actions for climate protection. The typology of adaptation actions which the work proposes may be helpful in research carried out in countries of a similar level of preparation for adaptation to climate change.
\end{abstract}

Keywords: municipal adaptation plan; climate threats; vulnerable sectors; expenditure; coastal zone; foothills; middle lowlands

\section{Introduction}

One of the most important challenges of the coming years is the adaptation of cities to functioning in the conditions of climate change [1-4]. Adopted at the turn of the 21st century, initial climate actions were aimed primarily at the mitigation of global warming. An example of such actions is the EU policy on mitigating climate change, of which the main aims were labelled as the Climate and Energy Package " $3 \times 20$ " [5]. In the case of Poland, whose energy sector according to the government's guidelines is to be connected primarily with bituminous coal and lignite up until $2040[6,7]$, the accepted goals more and more often are seen as too ambitious [8]. At present, it is becoming ever more certain that the global temperature increase and other climate changes cannot be limited by the end of the 21st century $[2,9,10]$. Thus, the adaptation of cities, where the majority of the world population lives, to climate change is becoming an increasingly pressing need [11,12].

The research conducted so far has revealed that most cities are not prepared for climate change or their preparations are at the initial stages [3,12-16]. According to the studies of [12], a mere $15 \%$ of cities with a population of over 1 million have undertaken any adaptation initiatives and $18 \%$ of the investigated cities have introduced climate change adaptation actions. The research in [10] assessed the scale of urban adaptation in the USA as low in comparison to other parts of the world, while $[17,18]$ claiming that U.S. cities have the lowest rate of adaptation planning $(59 \%$ of 
surveyed cities), with the vast majority of these (48\% of surveyed cities) in the preliminary planning and discussion phases. So far, in the majority of cities which have taken climate-oriented action, mitigation has prevailed over adaptation [15,17,19-21].

The choice of optimal adaptation solutions for cities [11,22,23] is difficult as it requires an individual approach and many options have to be considered regarding the rate, intensity, and scope of climate change $[2,9,24]$. One way of avoiding poor decisions is to use the experience of cities which have already implemented adaptation solutions. Thus, it is also necessary to fill gaps in knowledge and to create a base of knowledge regarding adaptation [16].

Despite the clear distinction between the terms 'mitigation' and 'adaptation' $[2,11,25]$ concerns remain as to whether the planned actions will help to mitigate climate change or adapt to it. A definite distinction is not always possible, even more so because some actions can both mitigate and support adaptation to climate change. For example, modernising public transport fleets not only reduces emissions but also improves the thermal conditions inside vehicles and increases passengers' safety during heat waves. Moreover, it is suggested that these actions should be balanced and complement each other $[16,26]$.

The adaptation measures taken are most often grouped into three categories: "coping", "incremental" and "transformative". While the first two concern remedial actions over a short or relatively short period, the last can lead to long-term and effective adaptation of a city to climate change [16]. An economic approach that embraces the following actions is sometimes used to assess measures: win-win, low-regret, no-regret, flexible [27]. Other ways of categorising adaptation measures have been proposed by [28-31], among others. Prepared on the basis of 92 projects in 70 countries, a universal typology comprising 10 categories of adaptation measures was offered by [11]. These ten categories are based on actual adaptation projects and, according to these authors, they can provide a foundation for comparisons, theoretical analyses, and actual adaptation measures. Diversity of the applied approaches may point to the need for their unification or at least checking whether the existing typology may be used widely, including the Polish conditions.

Scientific research on European and global adaptation has lacked information on the state of adaptation in Poland [14-16,21,27]. The climate change that is occurring in Poland has been confirmed by numerous studies that mainly indicated a temperature increase and a reduction of snow cover in winter [32-34]. So far, there have been no comprehensive studies regarding the adaptation of cities to the observed climate change. Due to the government project ADAPTcity (www.44mpa.pl) all Polish cities with a population of over 100,000 and another seven cities with a smaller population for the first time prepared their own plans of adaptation to climate change, which were successively approved throughout 2019 [35-48]. The only city which had already developed such a plan but did so again as part of this government project was Bydgoszcz [49]. The relatively late preparation of adaptation plans by cities in Poland may be a chance for them to use the "good practices" of other cities in this regard. The Polish municipal adaptation plans (MAPs) developed in 2017-2019 have not been so far a subject of scientific research.

The research aimed to determine the typology of adaptation measures adopted in the municipal adaptation plans (MAPs) of selected Polish cities, assess the scope of the planned measures quantitatively, thematically, financially and in terms of sectors, and also modify the typology of actions for adaptation of cities to climate change undertaken in East-Central Europe.

\section{Materials and Methods}

The material used for the research was the municipal adaptation plans published by the City Offices of the 14 cities taking part in the Ministry of the Environment's "Let's Feel the Climate" project. Only official documents published in the Bulletin of Public Information (BIP) or on websites of city offices were taken into account [35-48]; these documents are also available on the "Let's Feel the Climate" project's website. At the time of writing, most (12) of them had already been approved 
by City Councils; in two cases (Krakow and Sopot) the documents [40,44] were awaiting approval. They were all published only in Polish; therefore their content is not available to non-Polish speakers.

Municipal adaptation plans drawn up under the common "Let's Feel the Climate" project have a consistent graphic layout and content format. They are divided into nine chapters: a city's characteristics; linking the Adaptation Plan (AP) to strategic and planning documents; the method of AP development; public participation in AP development; diagnosis of problems; the vision of a city's adaptation and AP objectives; adaptation measures; AP implementation; conclusions. This is all complemented by attachments: (1) a list of stakeholders; (2) description of the main climate risks and their implications for the city; (3) graphic materials; (4) a forecast of the environmental impact of the relevant MAP project; (5) a strategic assessment of its impact on the environment. During the preparation of MAPs, cities cooperated with two organisations: coastal cities cooperated with the Polish Institute of Meteorology and Water Management; the remaining cities cooperated with design and consultancy firm "Arcadis sp. z o.o." (Ltd.)

The cities selected for the study are located in three different geographical regions: coastal (6 cities), middle lowlands (5 cities) and foothills (3 cities) (Figure 1).



Figure 1. The location of the cities considered in the research.

The selected cities are situated at an elevation of -1.6 m (Gdańsk) to 384 m (Rzeszów) above sea level and are inhabited by about 37,000 (Sopot) to 767,000 (Krakow) residents (Table 1). The presence of Sopot, which is relatively small, in the project is due to its exceptional position: it is a health resort which together with Gdynia and Gdańsk constitutes an urban agglomeration called "Tricity".

Table 1. Typical features of the investigated cities and the MAPs approval dates.

\begin{tabular}{cccccc}
\hline City & Latitude and Longitude & Hs [m a.s.1.] & Area $\left[\mathbf{k m}^{2}\right]$ & Number of Residents & MAP Approval Date \\
\hline \multicolumn{5}{c}{ Region: coastal zone } \\
\hline Elblag & $54^{\circ} 09^{\prime} 30^{\prime \prime} \mathrm{N} 19^{\circ} 24^{\prime} 10^{\prime \prime} \mathrm{E}$ & $1.8-92$ & 79.82 & 120,895 & $2019-04-18$ \\
\hline Gdańsk & $54^{\circ} 20^{\prime} 51^{\prime \prime} \mathrm{N} 18^{\circ} 38^{\prime} 43^{\prime \prime} \mathrm{E}$ & $-1.6-181$ & 261.96 & 464,293 & $2019-08-29$ \\
\hline Gdynia & $54^{\circ} 31^{\prime} 09^{\prime \prime} \mathrm{N} 18^{\circ} 32^{\prime} 22^{\prime \prime} \mathrm{E}$ & $0-206$ & 135.14 & 246,306 & $2019-04-24$ \\
\hline
\end{tabular}


Table 1. Cont.

\begin{tabular}{|c|c|c|c|c|c|}
\hline City & Latitude and Longitude & Hs [m a.s.l.] & Area $\left[\mathrm{km}^{2}\right]$ & Number of Residents & MAP Approval Date \\
\hline Sopot & $54^{\circ} 26^{\prime} 31^{\prime \prime} \mathrm{N} 18^{\circ} 33^{\prime} 35^{\prime \prime} \mathrm{E}$ & $0-153$ & 17.28 & 37,089 & pending approval \\
\hline Słupsk & $54^{\circ} 27^{\prime} 57^{\prime \prime} \mathrm{N} 17^{\circ} 01^{\prime} 45^{\prime \prime} \mathrm{E}$ & 22 & 43.15 & 92,869 & 2019-01-30 \\
\hline Szczecin & $53^{\circ} 26^{\prime} 17^{\prime \prime} \mathrm{N} 14^{\circ} 32^{\prime} 32^{\prime \prime} \mathrm{E}$ & $-0.1-131$ & 300.55 & 404,403 & $2019-05-28$ \\
\hline \multicolumn{6}{|c|}{ Region: middle lowlands } \\
\hline Bydgoszcz & $53^{\circ} 07^{\prime} 30^{\prime \prime} \mathrm{N} 18^{\circ} 00^{\prime} 40^{\prime \prime} \mathrm{E}$ & $28-107$ & 175.98 & 353,215 & 2019-09-04 \\
\hline Grudziądz & $53^{\circ} 29^{\prime} 13^{\prime \prime} \mathrm{N} 18^{\circ} 45^{\prime} 25^{\prime \prime} \mathrm{E}$ & 50 & 59.29 & 95,629 & 2019-06-19 \\
\hline Płock & $52^{\circ} 32^{\prime} 50^{\prime \prime} \mathrm{N} 19^{\circ} 42^{\prime} 00^{\prime \prime} \mathrm{E}$ & $58-105$ & 88.06 & 120,787 & 2019-01-31 \\
\hline Toruń & $53^{\circ} 01^{\prime} 20^{\prime \prime} \mathrm{N} 18^{\circ} 36^{\prime} 40^{\prime \prime} \mathrm{E}$ & $34-95$ & 115.72 & 202,482 & 2019-11-21 \\
\hline Włocławek & $52^{\circ} 39^{\prime} 39^{\prime \prime} \mathrm{N} 19^{\circ} 04^{\prime} 07^{\prime \prime} \mathrm{E}$ & 90 & 84.32 & 111,752 & 2019-02-19 \\
\hline \multicolumn{6}{|c|}{ Region: foothills } \\
\hline Kraków & $50^{\circ} 03^{\prime} 41^{\prime \prime} \mathrm{N} 19^{\circ} 56^{\prime} 18^{\prime \prime} \mathrm{E}$ & 188-383 & 326.85 & 766,739 & pending approval \\
\hline Tarnów & $50^{\circ} 01^{\prime} 45^{\prime \prime} \mathrm{N} 20^{\circ} 58^{\prime} 18^{\prime \prime} \mathrm{E}$ & 190-293 & 72.38 & 109,358 & 2019-09-12 \\
\hline Rzeszów & $50^{\circ} 02^{\prime} 01^{\prime \prime} \mathrm{N} 22^{\circ} 00^{\prime} 17^{\prime \prime} \mathrm{E}$ & $197-384$ & 126.57 & 190,849 & 2019-08-27 \\
\hline
\end{tabular}

The analysis of adaptation actions was preceded by a synthetic description of the main climatic threats identified by the teams preparing MAPs for the examined cities.

Chapter 7 of the selected cities' MAPs, which comprises a description of the planned "adaptation measures", was subjected to detailed analysis. In the first stage, each measure was assigned to one of the categories of adaptation types proposed by [11]. The basis for the assignment was the name of the measure and its description. During the analysis it was shown several times that a detailed description of a measure mentioned in a MAP consists of a few or more different "submeasures". When the description of tasks grouped under a common general name suggested a different character of measures to be implemented, the equal importance of all the mentioned different types of tasks was assumed. The number of measures was recorded in the form of their share in the measure (two different tasks were recorded as $\frac{1}{2}$ of each measure, three different tasks as $1 / 3$ etc.).

Moreover, analysis of the detailed provisions of plans showed that in some cases different tasks are planned under the same general name. For example, after detailed analysis of the investigated cities, a measure recorded as the "technical and non-technical protection of endangered buildings and infrastructure" usually turned out to be a task related to the construction of anti-flood embankments, water reservoirs, or the thermal modernisation of buildings. Similarly, in the provisions of the MAPs of Bydgoszcz and Gdańsk, under the name "Protection of areas generating fresh/cool air, ventilation corridors in urban areas", the description in the MAP for Bydgoszcz [35], describes "planning activities embracing the protection of urban ventilation and ecological corridors", whereas in the MAP for Gdańsk [37], this task is described as the "expansion of the air-quality monitoring system" and the unspecified "protection of fresh air generation". Thus, a detailed analysis of task descriptions made it clear that in some plans the same names are used for different measures. On the other hand, the names of the tasks are incompatible with the types of activities they contain, which could be assessed on the basis of their description. The wording of task names also varies from very general to more precise/specific, and some of the mentioned "specific" tasks can also be qualified as "general" (Appendix A).

In view of the above, the Authors adjusted the tasks to the selected types at two levels, comparing the achieved results of the classification of measures and making a final decision after arriving at a consensus. As some measures did not fit into any of the proposed types, two additional types were established: "pro-health programmes" and "mitigation measures" (Table 2). 
Table 2. Types of climate-oriented measures taken in cities.

\begin{tabular}{|c|c|c|}
\hline Type of Measures & Description of the Measures & $\begin{array}{l}\text { Examples of the Measures Recorded } \\
\text { in the MAPs }\end{array}$ \\
\hline Capacity building & Education programmes, workshops & $\begin{array}{l}\text { - education/promotion/information } \\
\text { about good practices } \\
\text { - preparation of operational instructions } \\
\text { for public services }\end{array}$ \\
\hline Management and planning & $\begin{array}{l}\text { Incorporating understanding of climate } \\
\text { risk into government and institutional } \\
\text { planning and management; developing } \\
\text { an adaptation plan }\end{array}$ & $\begin{array}{l}\text { - overview and correction of existing } \\
\text { urban crisis management models } \\
\text { - preparation of guidelines, analyses, } \\
\text { conceptions considering the need to } \\
\text { adapt a city for climate change }\end{array}$ \\
\hline Practice or behaviour & $\begin{array}{l}\text { Rainwater collection, } \\
\text { land management techniques }\end{array}$ & $\begin{array}{l}\text { - implementation of water } \\
\text { management programmes } \\
\text { - increasing the share of biologically } \\
\text { active surfaces by reducing } \\
\text { the impermeable surfaces in a city or } \\
\text { unsealing them }\end{array}$ \\
\hline Policy & $\begin{array}{l}\text { Creations, revisions or regulations of } \\
\text { policies to adapt to changing climate }\end{array}$ & $\begin{array}{l}\text { - development of water } \\
\text { management programmes }\end{array}$ \\
\hline Information & $\begin{array}{l}\text { Decision support tools, } \\
\text { communication tools, digital databases }\end{array}$ & $\begin{array}{l}\text { - gathering data on unfavourable } \\
\text { implications of threats } \\
\text { (including the loss of possessions) } \\
\text { - an internet tool for sharing knowledge } \\
\text { of adaptation }\end{array}$ \\
\hline Physical infrastructure & $\begin{array}{l}\text { Residential programmes, upgrades or } \\
\text { hardening of building and infrastructure }\end{array}$ & $\begin{array}{l}\text { - construction of water reservoirs with } \\
\text { the elements of } \\
\text { blue-green infrastructure } \\
\text { - protection of shores exposed to } \\
\text { the influence of waves }\end{array}$ \\
\hline Warning or observing systems & $\begin{array}{l}\text { Monitoring systems, } \\
\text { upgrade weather services }\end{array}$ & $\begin{array}{l}\text { - construction of a system providing } \\
\text { information about threats in } \\
\text { public space } \\
\text { - expansion of urban air } \\
\text { quality monitoring }\end{array}$ \\
\hline Green infrastructure & Tree planting and care, green roofs & $\begin{array}{l}\text { - creating flower meadows } \\
\text { - construction and development of parks }\end{array}$ \\
\hline Financing & New financing or insurance strategies & - "green" citizens' budget \\
\hline Technology & $\begin{array}{l}\text { Develop climate-resilient technologies: } \\
\text { to improve water use }\end{array}$ & $\begin{array}{l}\text { - a project of thermovision research } \\
\text { of buildings } \\
\text { - an energy efficiency park }\end{array}$ \\
\hline Health programmes & $\begin{array}{l}\text { Cooling centres, Shade Policy, help for } \\
\text { vulnerable people }\end{array}$ & $\begin{array}{l}\text { - construction of the solution system to } \\
\text { ensure a thermal comfort of inhabitants } \\
\text { - strengthening rescue services in } \\
\text { relation to climate change, exercises of } \\
\text { rescue services and equipment supply }\end{array}$ \\
\hline Mitigation & $\begin{array}{l}\text { Sustainable transportation, energy } \\
\text { efficiency, renewable energy }\end{array}$ & $\begin{array}{l}\text { - expansion of bike paths and pedestrian } \\
\text { routes (in the vicinity of } \\
\text { transport systems) } \\
\text { - programmes of heat source exchange } \\
\text { and installation of heating in buildings, } \\
\text { apartments and others }\end{array}$ \\
\hline
\end{tabular}

Based on: Biagini et al. 2014; the MAPs of 14 Polish cities up to 2030 [11,35-48].

Such an approach was adopted to consider both the quantitative structure of the proposed measures and the structure of financial means earmarked for the implementation of particular types of endeavours (here, the amount of funds was divided according to the equal share of particular tasks). It should be noticed that Grudziądz [39] did not include the division of funds into particular measures; 
in turn, in the MAPs of Bydgoszcz [35] the measures were divided into two parts, where the second part comprised measures without the prospect of financing; hence, they were excluded from this research.

What was also taken into account was the assumed deadlines of the implementation of particular measures and their relation (or lack of it) to one of the sectors/areas vulnerable to climate change assigned for Poland: water management, biological diversity and legally protected areas, forestry, the power industry, coastal zones, mountain areas, agriculture, transport, spatial management and urban areas, housing and health. Selection of sectors / areas vulnerable to climate change was made in accordance with the list included in the "Strategic adaptation plan for sectors vulnerable to climate change 2020, with an outlook to 2030" developed by the Polish Ministry of Environment in 2011-2013 [50].

\section{Results}

\subsection{Identification of Climate Hazards in Selected Cities}

The prepared MAPs [35-48] distinguish the most important climate hazards in Poland: heat, frost, heavy rain and storms, urban flooding, floods, coastal flooding, droughts, gales, landslides and rising sea level. Among the 14 MAPs discussed, all cities are endangered by heat; similarly, all of them except for Tarnów, located in the foothills (Table 1) [46] might encounter intense precipitation and storms (Table 3). The other most common threats that have been identified for 9-10 cities are urban flooding and droughts. Half of the investigated cities are endangered by floods and gales, whereas the least frequently identified threats are frost, coastal flooding, rising sea level (in four cities), and landslides (in Gdańsk and Płock) [37,42]. Except for the hazards related to a sea level rise, the remaining threats have been identified in all cities, regardless of their location (Figure 1, Table 3). In the coastal region, at least one city might be endangered by all of the aforementioned risks; in the middle lowlands, no city was identified as threatened by frost and gales.

Table 3. Main climate phenomena that pose a climate risk in selected cities in Poland (based on the MAPs of 14 cities up to 2030).

\begin{tabular}{|c|c|c|c|c|c|c|c|c|c|c|}
\hline City & Heat & Frost & $\begin{array}{l}\text { Heavy Rainfall } \\
\text { and Storms }\end{array}$ & Urban Flood & Flood & $\begin{array}{l}\text { Flood from } \\
\text { the Sea }\end{array}$ & Drought & Gale & Landslide & Sea Level Rise \\
\hline \multicolumn{11}{|c|}{ Region: coastal zone } \\
\hline Elblag & + & + & + & ++ & ++ & ++ & + & + & & + \\
\hline Gdańsk & + & & + & ++ & ++ & & + & + & + & ++ \\
\hline Gdynia & + & + & ++ & ++ & + & ++ & & + & & + \\
\hline Sopot & + & & + & ++ & & ++ & & + & & + \\
\hline Słupsk & + & ++ & ++ & ++ & + & & + & ++ & & \\
\hline Szczecin & + & & + & + & & + & & + & & \\
\hline \multicolumn{11}{|c|}{ Region: middle lowlands } \\
\hline Bydgoszcz & ++ & & ++ & & & & ++ & & & \\
\hline Grudziądz & + & & + & & & & ++ & & & \\
\hline Płock & ++ & & ++ & & + & & & & ++ & \\
\hline Toruń & ++ & & ++ & ++ & & & ++ & & & \\
\hline Włocławek & ++ & & + & & & & ++ & & & \\
\hline \multicolumn{11}{|c|}{ Region: foothills } \\
\hline Kraków & ++ & ++ & ++ & ++ & ++ & & & & & \\
\hline Tarnów & ++ & & & ++ & ++ & & ++ & & & \\
\hline Rzeszów & ++ & & ++ & ++ & & & ++ & + & & \\
\hline
\end{tabular}

++ very high probability of occurrence, + high probability of occurrence. 
The remaining threats mentioned in the MAPs [35-48] as being possible for parts of the investigated cities are chill waves, inter-diurnal temperature changes, urban heat islands, and pollution (Appendix B, Table A1). A phenomenon which will decline in importance with climate change in Poland is heavy snowfall in October to May (Appendix B, Table A2).

\subsection{Quantitative Classification of Measures Projected for MAPs}

The number of adaptation measures included in the MAPs of particular cities was from 11 (Słupsk, coastal zone) [43] to 36 (Płock, middle lowlands) [41] and does not depend on the city size (Table 1) [35-48]. In the first stage of the research, when classifying particular measures according to the typology of [11], it was stated that as many as $37 \%$ of tasks did not fit in any of the proposed types of adaptation measures. Among the tasks included in the designated types, the most (about 17\%) are of the "physical infrastructure" type, followed by the "green infrastructure" type (10\%). Polish cities least frequently plan measures concerning "financing" and "technologies" ( 0.2 and $1.4 \%$, respectively).

Analysis of the types of measures after modifying the typology of [11] showed that most of them could be classified as broadly understood mitigation (about 23\%) and "physical infrastructure" (about 17\%, Figure 2).

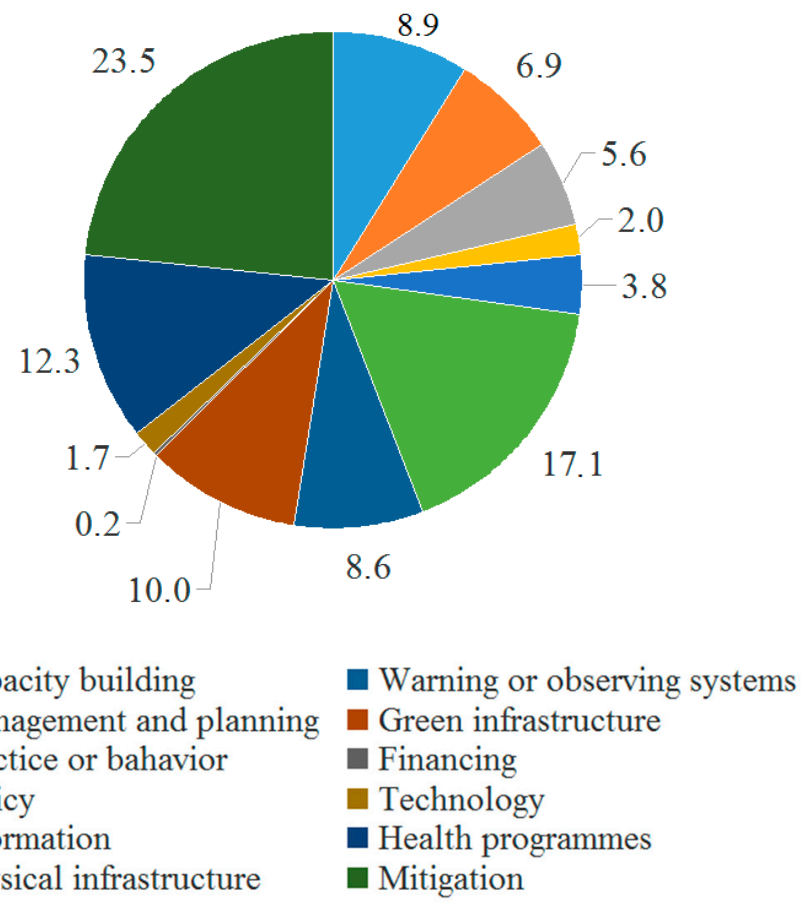

Figure 2. Share of individual types of measures (in \%) in the total number of actions in the MAPs of selected cities in Poland up to 2030.

The next in terms of quantity were pro-health measures and those concerning green infrastructure ( $12 \%$ and $10 \%$ of all measures, respectively). The tasks ranging from $5-10 \%$ of all measures are capacity building and education, practice and behaviour, management and planning, as well as warning and information systems. Measures concerning financing and technologies are the least frequently planned.

Among the measures mentioned in the MAPs of the investigated cities [35-48], "education/information about threats" appear most often and are included in the plans of 12 of the 14 cities. The second is "expansion of bike paths and pedestrian routes", which has been adopted by 11 out of the 14 cities. Only slightly less often, the following measures are planned in 9 out of the 14 cities: "building of a system to provide information about threats in public space", "construction and development of green and blue infrastructure", "adaptation of the public transport system to the effects of climate change" and "strengthening rescue services to take climate change into account, including the supply of new 
equipment". There are 44 individual tasks: for example, in the middle lowlands, developing a housing flood-protection concept (in Toruń) [47]; an update on and the preparation of a tourism development strategy adapted to climate change (in Płock) [41]; building of a toll collection system for the use of an urban storm water drainage system and the creation of flower meadows (in Grudziadz) [39]; and in the foothills, polder building (Krakow) [40]; providing investment areas with utilities (Rzeszów) [42]; construction of waste incineration plants (Tarnów) [46]. The city which has launched the most individual initiatives is Krakow. The remaining cities with individual initiatives were Płock (8), Torun and Tarnów (7 each), Grudziądz (6), Włocławek and Rzeszów (2 each).

\subsection{Classification of Finances Earmarked for Particular Types of Measures}

The surveyed cities plan to spend by far the largest pool of funds (as much as 63\%) on activities classified as mitigation (Figure 3).

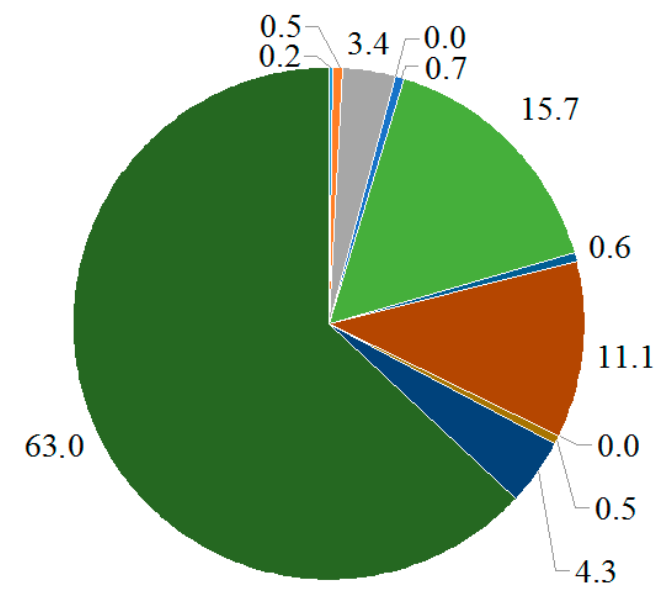

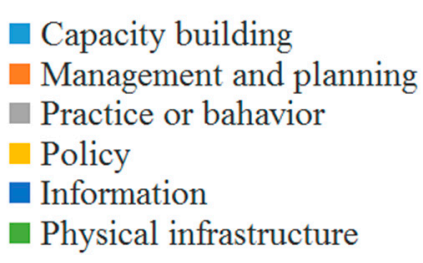

Warning or observing systems

Green infrastructure

Financing

Technology

- Health programmes

Mitigation

Figure 3. Share of the expenditure planned for individual types of measures (in \%) in the total spending on adaptation actions in the MAPs of selected cities in Poland up to 2030.

The next in terms of the amount of outlays are physical and green infrastructure, with, respectively, $16 \%$ and $11 \%$ of the total spending recorded in MAPs [35-48]. This is followed by two types of measures with about $4 \%$ of total spending each: "practice and behaviour" and pro-health programmes. Apart from the expenditure estimated for information $(0.67 \%)$, less than $0.5 \%$ of the total spending is planned for other types of measures. Among 14 of the investigated cities, five plan to allocate over $60 \%$ of all financial means to mitigation, and two (Szczecin, Toruń) plan to allocate over $80 \%$. A similar concentration of outlay can be observed only for expenditure on physical infrastructure, for which over $60 \%$ of funds are planned in three cities (Elblag, Gdańsk, Bydgoszcz). In two more cities (Płock, Słupsk) they constitute the largest item in the MAPs budget, accounting for over $40 \%$ of expenditure. The third largest expenditure group in the MAPs is green infrastructure, for which seven cities plan to allocate from $10 \%$ (Torun) to $40 \%$ of finances (Słupsk). It is worth noting that one of the cities (Sopot), located in the coastal zone (Figure 1), does not include any tasks related to green infrastructure. It is also worth noting that in two other cities in the coastal zone (Elblag and Szczecin) the second place in terms of the amount of outlays is taken by pro-health programmes, for which $11 \%$ and $8 \%$ of the total budget has been allocated, respectively. 
The smallest financial outlays are allocated for the most rarely planned measures: financing and technology. Moreover, it is surprising that no funds for "capacity building" (education) are planned in Tarnów (in the foothills).

\subsection{Time of the Planned Implementation of Measures in Municipal Adaptation Plans}

Generally, it can be noticed that the fastest implementation of all tasks is planned in Elblag, Sopot and Szczecin (coastal zone, Figure 1), for which the latest deadlines are 2028 (in Elblag-2025). In Płock, Tarnów and Włocławek, the MAPs [41,46,48] include tasks scheduled for 2019, whereas in Sopot [44] some tasks are even scheduled for 2018. In the last case, the MAP [44] has not been confirmed yet, which may suggest that the deadlines will be updated. Considering the time and type of tasks, one can notice that the majority (10 out of 14 ) of cities assume a longer implementation period that will last until 2030, mainly for measures related to physical infrastructure, followed by green infrastructure ( 9 out of 14 cities), and pro-health programmes ( 8 out of 14 cities). There are no task types whose implementation date would be clearly earlier. The 'financing' estimated for 2024 cannot be included here as this is a single case. Considering the tasks that will be implemented by 2020, one can notice that most cities (5 of 14) predict "practice and behaviour" tasks and the broadly understood "mitigation" type (mainly the improvement of transport systems), followed by some tasks from pro-health programmes (4 out of 14 cities).

\subsection{Measures by Vulnerable Sectors and Areas}

Overall, there are 11 sectors and areas that are vulnerable to climate change in Poland [50]. At least seven of these are related to urban areas, i.e., water management, biological diversity and legally protected areas, power industry, transport, spatial management and urban areas, housing and health. Moreover, for five of the investigated cities for which the possibility of a threat from the sea has been identified, the coastal zone is also recognised as vulnerable. Analysing the description of measures in the studied MAPs showed that most often (on average twice as often than in other cases) the cities plan adaptation in the water management and transport sectors (Figure 4). The tasks in these two sectors largely dominate other ones in Elblag (coastal zone), Toruń (middle lowlands), Krakow, Rzeszów, Tarnów (foothills). Most tasks related to water management are planned in Krakow, Płock, Rzeszów, Słupsk, Sopot (here together with spatial management), Elblag (also transport and a coastal economy) and Tarnów. Other sectors or vulnerable areas for which the largest number of tasks have been planned include biological diversity (in Bydgoszcz), a coastal zone (Gdańsk), transport (Grudziądz, Toruń), transport and coastal economy (Gdynia), a coastal zone, housing and spatial management (Szczecin), and health and transport (Włocławek).

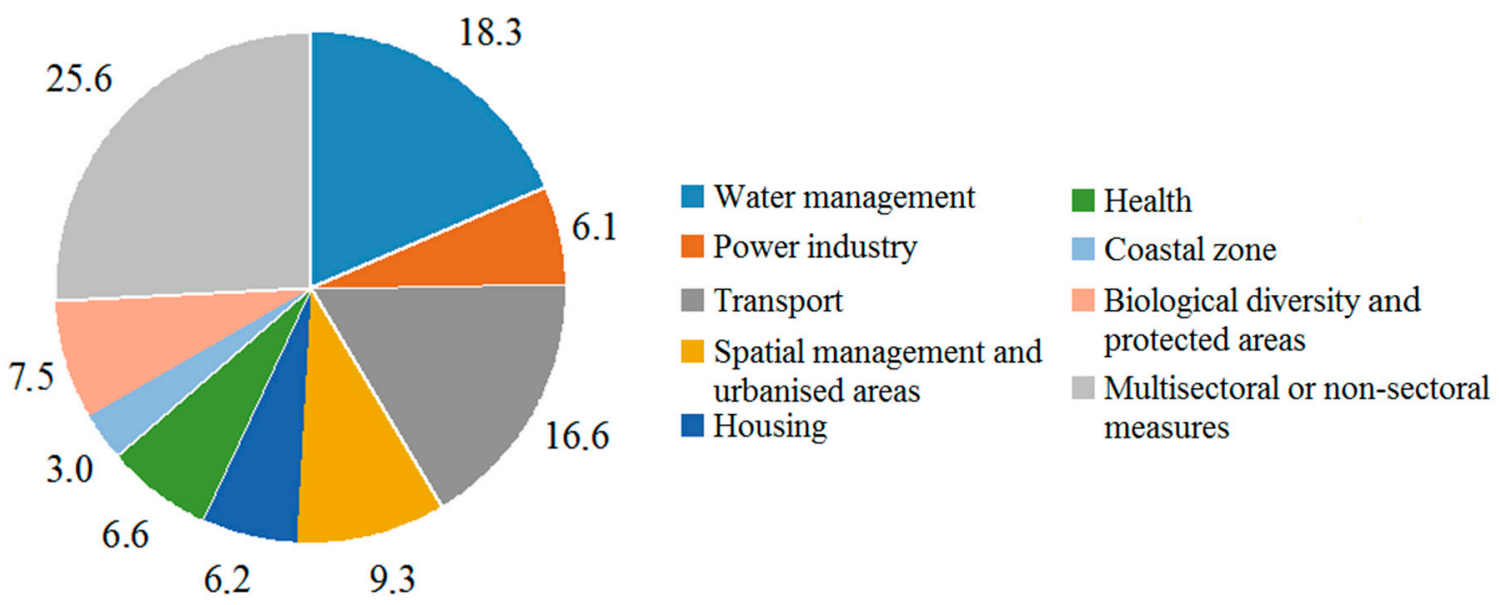

Figure 4. Share of the number of measures by sectors vulnerable to climate change (in \%) in the total number of actions included in the MAPs of selected cities in Poland. 
The next in terms of frequency are spatial management measures, whereas those most rarely planned are in housing, health, biological diversity and protected areas. About one fourth of the planned measures could not be included in any of the distinguished sectors or are multisectoral in nature: building of warning and observing systems, promotion of good practices, educational activities, strengthening rescue services, or the construction of sports and recreation facilities, including land development.

\section{Discussion}

The main climate change-related threats to cities around the world include rising temperatures, increasing intensity (rising temperature) of urban heat islands, heat waves, droughts, heavy rain, and rising sea levels in coastal areas [2,26,27]. All the mentioned phenomena are recognised as threats in the studied Polish cities. The risk of urban flooding, gales and (although most rarely) frost and landslides has also been identified. The research conducted so far in Poland has indicated a rise in air temperature primarily in the winter season, the growing phenomenon of drought, and an increasing number of extreme weather events such as torrential rains and whirlwinds [32-34,51]. Only the intensity and frequency of frost hazards are likely to decrease over time. In view of the above, it can be stated that despite being situated in a relatively mild climate, cities in Poland are subject to the same threats related to climate change as other cities in the world. The authors of [26] claim that global warming combined with urban heat islands will contribute to an increase in urban air pollution. It is worth emphasising that due to the present poor air quality in many cities in central and southern Poland, the growing threat of smog and excessive air pollution may become an additional specific problem in Polish cities [34,51,52].

Of the analysed measures included in the MAPs of the investigated cities and classified according to the typology created by [11], as many as 37\% of cases did not fit any of the proposed types of adaptation measures. This result differs from that obtained by [11], who stated that 93\% of measures conform fully to proposed categories, and the remaining $7 \%$ could be classified as more than one of them. Such an outcome might be indicative not so much of the imperfection of the suggested typology, but of the approach of cities. MAPs for particular cities included a lot of tasks planned by the authorities irrespective of climate change. Although the typology adopted in the research by [11] makes it possible to distinguish in detail the scope of adopted measures, it was not enough to classify all the tasks included in the analysed MAPs [35-48]. Difficulties with the clear-cut categorisation of a given measure as a specific type were indicated by [11]. An additional problem is that measures such as planting and caring for trees, green roofs, urban heating development can be classified as mitigation and adaptation. The introduced modification of this typology groups the actions specific for Polish cities better and can be applied in future studies, also out of Poland in the cities of a similar degree of adaptation to climate change. The issues of the research conducted in other countries of East-Central Europe, regarding e.g., perception of adaptation actions and adaptation pathways, are an example of a research area which should be considered also in Poland [53-55].

Among the tasks classified according to the typology of [11], most (about 17\%) fit the "physical infrastructure" and "green infrastructure" types (about 10\%). Polish cities least frequently plan activities in the fields of "financing" and "technologies" (0.2 and 1.4\%, respectively). The structure of measures deviates from that obtained by [11], in which the measures were most often qualified as capacity building, management and planning, practice and behaviour. In addition, [27] hold that the majority of adaptive measures can be categorised as "awareness-raising". The "capacity building" type in Polish cities seems to be underrated. The role of education and other "capacity building" tasks in adapting cities to climate change (mainly through changing human behaviour) was emphasized by [56]. It is worth noting the almost complete omission of "financing" measures. The importance of this problem was indicated by $[10,17]$.

Most of the tasks planned by 2030 by Polish cities are most often classified as modification activities and are mainly related to the modernization and expansion of transport systems [14,57], and in the very broad category of "physical infrastructure", i.e., activities related to the modernization 
of levees and construction of retention reservoirs. A total of $93 \%$ of urban areas in Great Britain recognise the modernisation of transport as a priority [20]. A significant share of measures related to transport, along with measures related to urban infrastructure and environmental actions, is also visible in the research on 100 cities across the world that was conducted by [24]. In the studies of [14], mitigation measures for European cities are most often related to transport. Concentration on measures related to transport is typical of cities in Central and South America [58,59]. The presence of numerous tasks related to the development of transport systems in the MAPs of Polish cities [35-48] may be associated with the ongoing equalisation of regional EU differences that started with Poland's accession to the EU in 2004, and the insufficient development of public transport [60,61].

Almost all the MAPs of the investigated cities include measures such as the "expansion of bike paths and pedestrian routes" and "adaptation of the public transport system to the effects of climate change". Many such tasks resulted in a large share of mitigation tasks in the general typology of measures included in the analysed MAPs.

In the research of [59], adaptation measures made up only $12 \%$ of all the measures taken in cities. Similarly, in the UK mitigation measures in cities were much more advanced than adaptation measures [20]. In the research of [15], which covered 200 cities in 11 European countries, 35\% of the cities had no dedicated mitigation plans, but as many as $72 \%$ had no adaptation plans at all. The UK, Finland and Germany are the most advanced in terms of adaptation planning in Europe, with rates ranging from $80 \%$ of cities (UK), through $50 \%$ (Finland) to $33 \%$ (Germany) and according to [21], also France (36\%) [14]. The coexistence of mitigation and adaptation measures in cities was mostly noticed in UK cities by [62], among other authors, but also in Finland and France, and the need to integrate both measures was indicated, e.g., by [14,57,63]. In turn, [64] as well as [15] claim that priority for mitigation measures is typical of cities that are just starting to undertake pro-climate actions. Other frequently recurring task types are "education/information about threats", "building of a system to provide information about threats in public space", "strengthening rescue services in relation to climate change, including the supply of new equipment" and "construction and development of green and blue infrastructure". The city which has launched the most individual initiatives is Krakow, the largest city covered in the research (Table 1). It is worth emphasising that this city has introduced a ban on the use of solid fuels in boilers, furnaces, and fireplaces [65].

When analysing specific tasks included in particular MAPs, it can be noted that the names of planned tasks are often identical. High repetitiveness of measures may prove the skilful use of patterns and good practices, but it could also be a result of a small number (three) of entities preparing draft plans commissioned by the offices of the 14 individual cities.

The investigated cities plan to allocate as much as $63 \%$ of resources for mitigation measures. Physical and green infrastructure are next in terms of the amount of outlays and will consume $16 \%$ and $11 \%$ of the total spending recorded in the MAPs. The absence in one of the plans (MAP Sopot) of the tasks connected with green infrastructure can be related to the fact that Sopot is a town of a high forest cover index (52\%), the highest among Polish towns [66].

Next there are practice and behaviour as well as health programmes, which will take about $4 \%$ each. Except for expenditure estimated for "education/information about threats" $(0.67 \%)$, less than $0.5 \%$ of total outlays will be allocated for the other types of measures. The importance of mitigation projects, mainly large road investments, is emphasized by their large share in the earmarked financial resources $(63 \%)$ compared to the much smaller share in the total number of tasks (approx. 25\%). Large outlays on mitigation are still observed: for example, [58] wrote about a $94 \%$ share in the investigated Latin American cities.

When considering the implementation period of particular types of adaptation measures, it can be noticed that most (10 out of 14) cities assume a longer completion term (until 2030) for some physical infrastructure tasks, followed by green infrastructure ( 9 out of 14 ) and pro-health programmes ( 8 out of 14 cities). There are no types of measures whose implementation would be explicitly completed earlier in all the investigated cities. Reckien et al. [14] point out that none of the mitigation strategies 
examined extend beyond 2050. In turn, Masson et al. [56] suggested that a timeframe of a century or more be taken into account when adapting cities to climate change.

Polish cities most often (on average twice as often as in other sectors) plan adaptation in 2 out of the 10 sectors regarded as vulnerable to climate: water management and transport. Next in terms of frequency are spatial management measures, whereas those planned the most rarely are in the housing, health, biological diversity and protection sectors. About one fourth of the planned measures are not included in any of the distinguished vulnerable sectors or are multisectoral in character. It can be noticed that cities vary in the number of measures planned in particular sectors. The designation of vulnerable sectors must be preceded by an analysis of local vulnerability to climate change $[50,67]$ (pp. 15-26), which took place in this case and was reflected in the mentioned differences between the MAPs of the investigated cities. This is also visible in the existing sectoral differences in climate-oriented measures adopted around the world [27,64]. The research of [14] shows that municipal adaptation plans in Europe contain the most frequent tasks that can be included in the town-planning and development, water management, health, anti-flood protection, forestry and agriculture sectors. Pursuant to the existing recommendations, plans for climate-oriented measures in a city should be integrative and comprehensive in character and should embrace various mitigating actions alongside adaptation measures $[26,56,58]$. Integration of mitigation and adaptation measures results in positive effects in terms of infrastructure development and prevents actions bringing counterproductive effects.

Finally, it is worth noting that in Poland it would be unrealistic to develop plans in all the largest cities without government support. By 2017, only one city in Poland had prepared an MAP. This is not a rule, however, that can be applied to all countries as sometimes government support is not enough $[15,68]$. In turn, [58] draw attention to the role that local authorities can play in cooperating with social organisations on reducing risk, including risk related to climate change. The key role of domestic governments in planning and implementing adaptation was highlighted in the IPCC report [9].

\section{Conclusions}

The main climate change-related threats to examined cities in Poland include rising temperatures, increasing intensity of a urban heat islands, heat waves, droughts, heavy rain, rising sea levels in coastal areas and, although most rarely, the risk of urban flooding, gales, frost and landslides.

The number of adaptation measures included in the MAPs of particular Polish cities was from 11 to 36 and does not depend on the city size. The adaptation measures planned by Polish cities and recorded in the MAPs as part of the government "Let's Feel the Climate" project are characterized by numerous measures regarding physical and green infrastructure. "Financing" and "technologies" were the most rarely planned measures in Polish cities. The vulnerable sectors for which the most tasks are planned are water management and transport.

This specific character resulted in a necessity to adjust the existing typology of adaptation actions to the conditions of Poland. The measures recorded in the MAPs are often unclear and sometimes too broad: many tasks with different scopes are put under one general name, which could make it difficult to assess the execution of a planned measure. In spite of the "Adaptation Handbook for Cities" prepared by the Polish Ministry of Environment, a precise catalogue which would put the undertaken actions in order is lacking. The conducted research revealed the need for developing a catalogue of adaptation actions according to types. Such a catalogue would be useful both in research studies and verification procedures of MAPs.

A large number of tasks and the even bigger scale of financial outlays predicted in the investigated MAPs for mitigation tasks may show that Polish cities are in the initial stages of measures regarding climate protection. The implementation of most tasks in the analysed MAPs is planned to be complete by 2030; however, there are quite large differences between cities. Most often, the cities planned adaptation in 2 out of 10 sectors regarded as vulnerable to climate: water management and transport; on average twice as frequently as in the other sectors. 
The research results could be of significance during the implementation of the postulated modification of the original versions of plans and could facilitate finding a balance between the scope of mitigation and adaptation measures. The information contained in this work could contribute to filling the existing gap in knowledge about adaptation and creating a store of such knowledge. Furthermore, it opens the way for other directions of research.

Author Contributions: Conceptualization, E.K.; methodology, E.K., R.K.; formal analysis, E.K., R.K.; investigation, E.K.; resources, R.K.; writing-original draft preparation, E.K.; writing—review and editing, E.K., R.K.; visualization, E.K., R.K. All authors have read and agreed to the published version of the manuscript.

Funding: This research received no external funding.

Conflicts of Interest: The authors declare no conflict of interest.

\section{Appendix A}

The names of the tasks are incompatible with the types of activities they contain, which could be assessed on the basis of their description. For instance, in the MAP of Słupsk, in point two next to the name of the "construction and development of the blue and green infrastructure (BGI) system" measure, the detailed description includes measures such as educational activities aiming at "raising the social awareness of benefits provided by the BGI measure".

The wording of task names also varies from very general to more precise/specific, and some of the mentioned "specific" tasks can also be qualified as "general". This can be illustrated by the "construction and development of green infrastructure" and "construction and development of parks" measures. A somewhat different approach was adopted by the authors of the MAPs for Szczecin, who wrote several examples of the same tasks whose implementation is planned under different main tasks. For example, the "construction of an amphitheatre" and the "development of Szczecin Dabie airport and the surrounding area" are given as exemplary submeasures within the following measures: "protection of areas generating fresh/cool air", "construction of a system to ensure the thermal comfort of residents", "construction and development of a blue and green infrastructure system" and "increasing the share of biologically active surfaces by reducing and unsealing the impermeable surfaces in the city". The second submeasure concerning the airport also comes under the measure "strengthening the potential of rescue services in relation to climate change adaptation". 


\section{Appendix B}

Table A1. Identified climate phenomena that pose a climate risk in selected cities in Poland (based on the MAPs of 14 cities up to 2030). Part I.

\begin{tabular}{|c|c|c|c|c|c|c|c|c|c|}
\hline City & $\begin{array}{c}\text { Maximum } \\
\text { Temperature }\end{array}$ & $\begin{array}{c}\text { Minimum } \\
\text { Temperature }\end{array}$ & Heat Wave & Cold Wave & $\begin{array}{c}\text { Inter-Day } \\
\text { Temperature Change }\end{array}$ & $\begin{array}{l}\text { Urban Heat } \\
\text { Island }\end{array}$ & $\begin{array}{l}\text { Air Pollution } \\
\text { Concentration }\end{array}$ & $\begin{array}{c}\text { Strong and Very } \\
\text { Strong Wind }\end{array}$ & $\begin{array}{c}\text { Thunderstorms, } \\
\text { Hailstorms }\end{array}$ \\
\hline \multicolumn{10}{|c|}{ Region: coastal zone } \\
\hline Elblag & + & & + & & & & & + & + \\
\hline Gdańsk & + & & + & & & & & + & + \\
\hline Gdynia & + & & + & & & & & + & + \\
\hline Sopot & + & & + & & & & & + & + \\
\hline Słupsk & ++ & ++ & + & ++ & & & & ++ & ++ \\
\hline Szczecin & + & + & + & + & + & + & + & + & + \\
\hline \multicolumn{10}{|c|}{ Region: middle lowlands } \\
\hline Bydgoszcz & ++ & & ++ & & & ++ & ++ & ++ & ++ \\
\hline Grudziądz & ++ & & ++ & - & ++ & + & + & ++ & ++ \\
\hline Płock & ++ & & ++ & & & ++ & ++ & & \\
\hline Toruń & ++ & & ++ & ++ & ++ & ++ & ++ & ++ & ++ \\
\hline Włocławek & ++ & & ++ & & & ++ & ++ & & \\
\hline \multicolumn{10}{|c|}{ Region: foothills } \\
\hline Kraków & & & ++ & ++ & & & & ++ & ++ \\
\hline Tarnów & ++ & & ++ & & & & ++ & & \\
\hline Rzeszów & ++ & ++ & ++ & & & & ++ & & \\
\hline
\end{tabular}

++ high probability of the occurrence, + mid-probability of the occurrence, - a threat of decreasing importance. 
Table A2. Identified climate phenomena that pose a climate risk in selected cities in Poland (based on the MAPs of 14 cities up to 2030). Part II.

\begin{tabular}{|c|c|c|c|c|c|c|c|c|c|}
\hline City & Sea Level Rise & Heavy Downpours & $\begin{array}{l}\text { Heavy Snowfalls in } \\
\text { the Oct.-May Season }\end{array}$ & $\begin{array}{c}\text { Long-Term } \\
\text { Rain-Free Periods }\end{array}$ & $\begin{array}{l}\text { Rain-Free Periods with } \\
\text { a High Temperature }\end{array}$ & Water Shortage & River Floods & $\begin{array}{c}\text { Flooding } \\
\text { from the Sea }\end{array}$ & Flash/Urban Floods \\
\hline \multicolumn{10}{|c|}{ Region: coastal zone } \\
\hline Elblag & ++ & + & - & & + & & ++ & ++ & ++ \\
\hline Gdańsk & ++ & + & - & & & & ++ & ++ & ++ \\
\hline Gdynia & ++ & ++ & & & & & ++ & ++ & ++ \\
\hline Sopot & ++ & + & & & & & & ++ & ++ \\
\hline Słupsk & & ++ & & & ++ & & & & ++ \\
\hline Szczecin & + & + & & & + & + & & + & + \\
\hline \multicolumn{10}{|c|}{ Region: middle lowlands } \\
\hline Bydgoszcz & & ++ & & ++ & & ++ & ++ & & \\
\hline Grudziądz & & ++ & - & ++ & & + & & & + \\
\hline Płock & & ++ & & & & & ++ & & \\
\hline Toruń & & ++ & & & ++ & ++ & & & ++ \\
\hline Włocławek & & & & & ++ & & & & \\
\hline \multicolumn{10}{|c|}{ Region: foothills } \\
\hline Kraków & & ++ & & & ++ & & ++ & & ++ \\
\hline Tarnów & & ++ & & & ++ & & ++ & & ++ \\
\hline Rzeszów & & ++ & & & ++ & & & & ++ \\
\hline
\end{tabular}

++ high probability of the occurrence, + mid-probability of the occurrence, - a threat of decreasing importance. 


\section{References}

1. Mills, G.; Cleugh, H.; Emmanuel, R.; Endlicher, W.; Erell, E.; McGranahan, G.; Ng, E.; Nickson, A.; Rosenthal, J.; Steemer, K. Climate information for improved planning and management of mega cities (Needs Perspective). Procedia Environ. Sci. 2010, 1, 228-246. [CrossRef]

2. Sharma, D.; Tomar, S. Mainstreaming climate change adaptation in Indian cities. Environ. Urban. 2010, 22, 451-465. [CrossRef]

3. Carter, J.G. Climate change adaptation in European cities. Curr. Opin. Environ. Sustain. 2011, 3, $193-198$. [CrossRef]

4. Bai, X.; Dawson, R.J.; Ürge-Vorsatz, D.; Delgado, G.C.; Barau, A.S.; Dhakal, S.; Dodman, D.; Leonardsen, L.; Masson-Delmotte, V.; Roberts, D.; et al. Six research priorities for cities and climate change. Nature 2018, 555, 23-25. [CrossRef]

5. 2020 Climate \& Energy Package. Available online: https://ec.europa.eu/clima/policies/strategies/2020_en (accessed on 6 September 2020).

6. Polityka Energetyczna Polski Do 2030 Roku (Poland's Energy Policy until 2030). Available online: https: //www.gov.pl/web/klimat/polityka-energetyczna-polski-do-2030-roku (accessed on 6 September 2020).

7. Polityka Energetyczna Polski do Roku 2040-Projekt (Poland's Energy Policy until 2040—Draft). Available online: https:/www.gov.pl/web/aktywa-panstwowe/zaktualizowany-projekt-polityki-energetycznejpolski-do-2040-r (accessed on 6 September 2020).

8. Climate for Poland, Poland for Climate 1988-2018-2050. Available online: https://ios.edu.pl/wp-content/ uploads/2019/03/Klimat-dla-Polski-Polska-dla-Klimatu_ANG-1.pdf (accessed on 6 September 2020).

9. Intergovernmental Panel on Climate Change (IPCC). Climate Change 2014: Impacts, Adaptation, and Vulnerability. IPCC Working Group II Contribution to AR5 2014. Available online: http://ipcc-wg2.gov/AR5/ (accessed on 29 May 2020).

10. Hughes, S. A meta-analysis of urban climate change adaptation planning in the U.S. Urban Clim. 2015, 14, 17-29. [CrossRef]

11. Biagini, B.; Bierbaum, R.; Stults, M.; Dobardzic, S.; McNeeley, S.M. A typology of adaptation actions: A global look at climate adaptation actions financed through the Global Environment Facility. Glob. Environ. Chang. 2014, 25, 97-108. [CrossRef]

12. Araos, M.; Berrang-Ford, L.; Ford, J.D.; Austin, S.E.; Biesbroek, R.; Lesnikowski, A. Climate change adaptation planning in large cities: A systematic global assessment. Environ. Sci. Policy 2016, 66, 375-382. [CrossRef]

13. Mahammadzadeh, M.; Chrischilles, E.; Biebeler, H. Klimaanpassung in Unternehmen und Kommunen: Betroffenheiten, Verletzlichkeiten und Anpassungsbedarf; IW-Analysen; Institut der Deutschen Wirtschaft: Cologne, Germany, 2013.

14. Reckien, D.; Flacke, J.; Dawson, R.J.; Heidrich, O.; Olazabal, M.; Foley, A.; Hamann, J.J.-P.; Orru, H.; Salvia, M.; De Gregorio Hurtado, S.; et al. Climate change response in Europe: What's the reality? Analysis of adaptation and mitigation plans from 200 urban areas in 11 countries. Clim. Chang. 2014, 122, 331-340. [CrossRef]

15. Reckien, D.; Flacke, J.; Olazabal, M.; Heidrich, O. The influence of drivers and barriers on urban adaptation and mitigation plans-an empirical analysis of European cities. PLoS ONE 2015, 10, e0135597. [CrossRef]

16. EEA. Urban Adaptation to Climate Change in Europe2016: Transforming Cities in a Changing Climate; Report 12/2016; Publications Office of the European Union: Luxembourg, 2016. [CrossRef]

17. Aylett, A. Progress and Challenges in the Urban Governance of Climate Change: Results of a Global Survey; Massachusetts Institute of Technology-Department of Urban Studies and Planning: Cambridge, MA, USA, 2014.

18. Carmin, J.; Nadkarni, N.; Rhie, C. Progress and Challenges in Urban Climate Adaptation Planning: Results of a Global Survey; MIT: Cambridge, MA, USA, 2012.

19. Liu, J.; Deng, X. Impacts and mitigation of climate change on Chinese cities. Curr. Opin. Environ. Sustain. 2011, 3, 188-192. [CrossRef]

20. Heidrich, O.; Dawson, R.J.; Reckien, D.; Walsh, C.L. Assessment of the climate preparedness of 30 urban areas in the UK. Clim. Chang. 2013, 120, 771-784. [CrossRef]

21. Heidrich, O.; Reckien, D.; Olazabal, M.; Foley, A.; Salvia, M.; de Gregorio Hurtado, S.; Orru, H.; Flacke, J.; Geneletti, D.; Pietrapertosa, F.; et al. National climate policies across Europe and their impacts on cities strategies. J. Environ. Manag. 2016, 168, 36-45. [CrossRef] [PubMed] 
22. Canadell, J.G.; Raupach, M.R. Managing forests for climate change mitigation. Science 2008, 320, $1456-1457$. [CrossRef] [PubMed]

23. Knittel, N. Climate Change Adaptation: Options and Mechanisms under the UNFCCC". Climate Policy Info Hub, 29 March 2016. Available online: http://climatepolicyinfohub.eu/climate-change-adaptation-optionsand-mechanisms-under-unfccc (accessed on 6 September 2020).

24. Castán Broto, V.; Bulkeley, H. A survey of urban climate change experiments in 100 cities. Glob. Environ. Chang. 2013, 23, 92-102. [CrossRef] [PubMed]

25. Füsell, H.-M.; Klein, R.J.T. Climate change vulnerability assessments: An evolution of conceptual thinking. Clim. Chang. 2006, 75, 301-329. [CrossRef]

26. Rosenzweig, C.; Solecki, W.; Romero-Lankao, P.; Mehrotra, S.; Dhakal, S.; Bowman, T.; Ibrahim, S.A. ARC3.2 Summary for city leaders. In Urban Climate Change Research Network; Columbia University: New York, NY, USA, 2015.

27. Hunt, A.; Watkiss, P. Climate change impacts and adaptation in cities: A review of the literature. Clim. Chang. 2011, 104, 13-49. [CrossRef]

28. Tompkins, E.L.; Adger, W.N.; Boyd, E.; Nicholson-Cole, S.; Weatherhead, K.; Arnel, N. Observed adaptation to climate change: UK evidence of transition to a well-adapting society. Glob. Environ. Chang. 2010, 20, 627-635. [CrossRef]

29. Travis, W. Going to extremes: Propositions on the social response to severe climate change. Clim. Chang. 2010, 98, 1-19. [CrossRef]

30. Eisenack, K.; Stecker, R.; Reckien, D.; Hoffmann, E. Adaptation to climate change in the transport sector: A review of actions and actors. Mitig. Adapt. Strat. Glob. Chang. 2012, 17, 451-469. [CrossRef]

31. Fidelman, P.I.J.; Leitch, A.M.; Nelsond, D.R. Unpacking multilevel adaptation to climate change in the Great Barrier Reef, Australia. Glob. Environ. Chang. 2013, 23, 800-812. [CrossRef]

32. Łabędzki, L. Actions and measures for mitigation drought and water scarcity in agriculture. J. Water Land Dev. 2016, 29, 3-10. [CrossRef]

33. Tylkowski, J. Extreme weather events in Poland in the 21st century. J. Educ. Health Sport 2017, 7, 40-51. [CrossRef]

34. Kalbarczyk, R.; Kalbarczyk, E.; Ziemiańska, M.; Raszka, B. Assessment of air thermal conditions in the lowland part of south-western Poland for agriculture development purposes. Atmosphere 2018, 9, 215. [CrossRef]

35. MAP Bydgoszcz. Available online: https://bip.um.bydgoszcz.pl/binary/Planu\%20adaptacji\%20miasta\% 20Bydgoszczy\%20do\%20zmian\%20klimatu\%20do\%20roku\%202030_tcm30-258424.pdf (accessed on 29 May 2020).

36. MAP Elblag. Available online: http://www.marecki.home.pl/images/PLIKI/plan_adaptacji_do_zmian_ klimatu.pdf (accessed on 29 May 2020).

37. MAP Gdańsk. Available online: https://www.gdansk.pl/download/2018-11/117491.pdf (accessed on 29 May 2020).

38. MAP Gdynia. Available online: https://bip.um.gdynia.pl/programy-w-2020-roku,8228/plan-adaptacjimiasta-gdyni-do-zmian-klimatu-do-roku-2030,541418 (accessed on 29 May 2020).

39. MAP Grudziądz. Available online: http://bip.grudziadz.pl/strony/17312.dhtml (accessed on 29 May 2020).

40. MAP Kraków. Available online: https://www.bip.krakow.pl/?dok_id=114317 (accessed on 29 May 2020).

41. MAP Płock. Available online: http://dane.plock.eu/bip//dane/uchwaly/8\%20kadencja\%20RMP/4/Uchwa|T1 la\%8.20nr\%2058.pdf (accessed on 29 May 2020).

42. MAP Rzeszów. Available online: https://bip.erzeszow.pl/static/img/k02/SR/SR/Plan_adaptacji_miasta_ Rzeszowa_do_zmian_klimatu_do_2030_roku.pdf (accessed on 29 May 2020).

43. MAP Słupsk. Available online: www.bip.um.slupsk.pl/file/70125 (accessed on 29 May 2020).

44. MAP Sopot (Project). Available online: https://bip.sopot.pl/Article/get/id,18916.html (accessed on 29 May 2020).

45. MAP Szczecin. Available online: http://bip.um.szczecin.pl/files/1F59A64A3FE640B99C6349D70BA76DE5/ MPA_SzczecinBIP_9_listopada18.pdf (accessed on 29 May 2020).

46. MAP Tarnów. Available online: http://tarnow.esesja.pl/zalaczniki/58453/plan-adaptacji-miasta-tarnowa-dozmian-klimatu_529938.pdf (accessed on 29 May 2020).

47. MAP Toruń. Available online: https://www.torun.pl/sites/default/files/pliki/plan_adaptacji_miasta_torunia_ do_zmian_klimatu_do_roku_2030.pdf (accessed on 29 May 2020).

48. MAP Włocławek. Available online: http://www.bip.um.wlocl.pl/uchwala-w-sprawie-przyjecia-planuadaptacji-miasta-wloclawek-do-zmian-klimatu-do-roku-2030/ (accessed on 29 May 2020). 
49. MAP 2012. Bydgoszcz. Available online: https://docplayer.pl/13601995-Plan-ochrony-klimatu-i-adaptacjido-skutkow-zmian-klimatu-dla-miasta-bydgoszczy-na-lata-2012-2020.html (accessed on 29 May 2020).

50. SPA 2013. Available online: https://bip.mos.gov.pl/strategie-plany-programy/strategiczny-plan-adaptacji2020/ (accessed on 9 January 2020).

51. Kalbarczyk, R.; Kalbarczyk, E.; Raszka, B. Temporal changes in concentration of PM10 dust in Poznań, middle-west Poland as dependent on meteorological conditions. Appl. Ecol. Environ. Res. 2018, 16, 1999-2014. [CrossRef]

52. Kalbarczyk, R.; Kalbarczyk, E. Meteorological conditions of the winter-time distribution of nitrogen oxides in Poznań: A proposal for a catalog of the pollutants variation. Urban Clim. 2020, 33, 100649. [CrossRef]

53. Li, S.; Juhász-Horváth, L.; Harrison, P.A.; Pintér, L.; Rounsevell, M.D.A. Relating farmer's perceptions of climate change risk to adaptation behaviour in Hungary. J. Environ. Manag. 2017, 185, 21-30. [CrossRef]

54. Zandvoort, M.; Campos, I.S.; Vizinho, A.; Penha-Lopes, G.; Krkoška Lorencová, E.; van der Brugge, R.; van der Vlist, M.J.; van den Brink, A.; Jeuken, A.B.M. Adaptation pathways in planning for uncertain climate change: Applications in Portugal, the Czech Republic and the Netherlands. Environ. Sci. Policy 2017, 78, 18-26. [CrossRef]

55. Krkoška Lorencová, E.; Loučková, B.; Vačkářů, D. Perception of climate change risk and adaptation in the Czech Republic. Climate 2019, 7, 61. [CrossRef]

56. Masson, V.; Marchadier, C.; Adolphe, L.; Aguejdad, R.; Avner, P.; Bonhomme, M.; Bretagne, G.; Briottet, X.; Bueno, B.; de Munck, C.; et al. Adapting cities to climate change: A systemic modelling approach. Urban Clim. 2014, 10, 407-429. [CrossRef]

57. Walsh, C.L.; Dawson, R.J.; Hall, J.W.; Barr, S.L.; Batty, M.; Bristow, A.L.; Carney, S.; Dagoumas, A.S.; Ford, A.C.; Harpham, C.; et al. Assessment of climate change mitigation and adaptation in cities. Urban Des. Plan. 2011, 164, 75-84. [CrossRef]

58. Hardoy, J.; Lankao, P.R. Latin American cities and climate change: Challenges and options to mitigation and adaptation responses. Curr. Opin. Environ. Sustain. 2011, 3, 158-163. [CrossRef]

59. Bulkeley, H.; Castán Broto, V. Government by experiment? Global cities and the governing of climate change. Trans. Inst. Br. Geogr. 2013, 38, 361-375. [CrossRef]

60. Szczuraszczek, T.; Chmielewski, J. Sustainable transport development and passenger transport demand in Poland. In Proceedings of the 3rd Scientific Conference Environmental Challenges in Civil Engineering (ECCE 2018) (MATEC Web of Conferences), Opole, Poland, 23-25 April 2018; Volume 174, p. 01021. [CrossRef]

61. Taczanowski, J.; Kołoś, A.; Gwosdz, K.; Domański, B.; Guzik, R. The development of low-emission public urban transport in Poland. Bull. Geogr. Soc.-Econ. Ser. 2018, 41, 79-92. [CrossRef]

62. Charlesworth, S.M. A review of the adaptation and mitigation of global climate change using sustainable drainage in cities. J. Water Clim. Chang. 2010, 1, 165-180. [CrossRef]

63. Ayers, J.; Huq, S.; Wright, H.; Faisal, A.M.; Hussain, S.T. Mainstreaming climate change adaptation into development in Bangladesh. Clim. Dev. 2014, 6, 293-305. [CrossRef]

64. Roberts, D.; O'Donoghue, S. Urban environmental challenges and climate change action in Durban, South Africa. Environ. Urban. 2013, 25, 299-319. [CrossRef]

65. Official Journal of the Voivodeship 2016. Available online: http://edziennik.malopolska.uw.gov.pl/legalact/ 2016/812/ (accessed on 9 January 2020).

66. BDL 2019. Statistics Poland. Available online: https://bdl.stat.gov.pl/BDL/dane/podgrup/tablica (accessed on 9 January 2020).

67. Podręcznik adaptacji dla miast. Wytyczne do przygotowania Miejskiego Planu Adaptacji do zmian klimatu (Adaptation Handbook for Cities. Guidelines for the Preparation of the Municipal Plan of Adaptation to Climate Change). Available online: https://klimada.mos.gov.pl/wp-content/uploads/2015/09/Podr\%C4\% 99cznik-adaptacji-dla-miast1.pdf (accessed on 6 September 2020).

68. Kettle, N.P.; Dow, K. Cross-level differences and similarities in coastal climate change adaptation planning. Environ. Sci. Policy 2014, 44, 279-290. [CrossRef]

(C) 2020 by the authors. Licensee MDPI, Basel, Switzerland. This article is an open access article distributed under the terms and conditions of the Creative Commons Attribution (CC BY) license (http://creativecommons.org/licenses/by/4.0/). 